\title{
Deteksi Protozoa Usus Oportunistik pada Penderita Diare Anak di Puskesmas Rawat Inap Pekanbaru
}

\author{
Esy Maryanti*, Suri Dwi Lesmana ${ }^{1}$, Hendro Mandela ${ }^{2}$
}

\begin{abstract}
Diarrhea is still a public health problem, especially in developing countries. Diarrhea causes morbidity and high mortality in children. Diarrhea can be caused by viruses, bacteria, parasites and food poisoning. One of the parasite that can cause diarrhea is intestinal protozoa. Lately, attention to intestinal opportunistic protozoan infections is increasing. Opportunistic intestinal protozoa infection is an infection by intestinal protozoa that had not considered important and now can cause disease in humans. Cryptosporidium sp, Cyclospora cayetanensis, Isospora belii and Blastocystis hominis are opportunistic intestinal protozoa. The clinical manifestations of the infection depends on the immune status of patients, ranging from asymptomatic in immunocompetent individuals to chronic diarrhea not cured and fatal in patients imunokompromis. This study aims to detect opportunistic intestinal protozoa in children with diarrhea patients in health centers Inpatient Pekanbaru used modified acid fast stain procedure. A total of 76 samples tested positive obtained $22.3 \%$ of opportunistic intestinal protozoa found that $9.2 \%$ were infected with Cryptosporidium sp, Cyclospora infection were $2.6 \%$ and Blastocystis hominis $10.5 \%$, while Isospora not found.
\end{abstract}

Keywords: opportunistic intestinal protozoa, diarrhea, children

Diare di Indonesia masih merupakan masalah kesehatan utama karena masih sering menimbulkan kejadian luar biasa (KLB) dan kadang disertai kematian. ${ }^{1}$ Berdasarkan data dari Dinas Kesehatan Provinsi Riau Tahun 2009, kajian dan analisis dari beberapa survei yang dilakukan, angka kesakitan diare pada semua golongan umur adalah 423/1000 penduduk. Episode diare pada golongan balita adalah 1,5 kali per tahun. Angka kematian diare pada semua golongan umur 54/100.000 penduduk dan pada balita terjadi 55.000 kematian $(2,5 / 1.000$ balita). ${ }^{2}$

Diare dapat disebabkan oleh virus, bakteri, parasit dan keracunan makanan. Salah satu parasit yang dapat menyebabkan diare adalah protozoa usus. ${ }^{3}$ Infeksi protozoa usus merupakan masalah kesehatan di dunia khususnya negara berkembang dan akhir-akhir ini perhatian terhadap infeksi protozoa usus semakin meningkat khususnya infeksi

\footnotetext{
1. Penulis untuk korespondensi : Bagian Parasitologi Fakultas Kedokteran Universitas Riau,

* Alamat : Jl. Diponegoro No. 1 Telp. 0761-839264, ext 209 email:esy.maryanti@gmail.com

2. Fakultas Kedokteran Universitas Riau
}

protozoa usus oportunistik. Infeksi protozoa usus oportunistik merupakan infeksi oleh protozoa usus yang dulu tidak dianggap penting dan sekarang dapat menimbulkan penyakit pada manusia.,

Parasit yang termasuk dalam protozoa usus oportunistik yang sering ditemukan pada manusia baru-baru ini adalah Cryptosporidium $s p$, Cyclospora cayetanensis, Isospora belii dan Blastocystis hominis. ${ }^{3,5}$ Parasit ini dapat menimbulkan gejala klinis diare. Manifestasi klinis dari infeksi tersebut tergantung kepada status imun penderita, mulai dari asimptomatis sampai dengan gejala berat seperti diare kronis yang tidak sembuh dan berakibat fatal. Infeksi ini sering ditemukan pada individu imunokompromais. ${ }^{3}$

Penelitian di India tahun 2009 dilaporkan bahwa terdapat $62,5 \%(n=48)$ kasus infeksi protozoa usus oportunistik pada pasien HIV, dan Cryptosporidium parvum merupakan patogen yang terbanyak ditemukan (50\%). ${ }^{6}$ Pada penelitian di Jakarta tahun 2004-2007, dilaporkan 72,4\% ( $\mathrm{n}=194)$ penderita HIV/AIDS dengan diare terinfeksi Blastocystis hominis, dan 12\% terinfeksi dengan Cryptosporidium sp. ${ }^{7}$ 
Infeksi protozoa usus oportunistik tersebut selain ditemukan pada pasien imunokompromais juga dilaporkan dapat menginfeksi anak. Pada kasus kriptosporidiosis yaitu infeksi oleh Cryptosporydium $s p$, dilaporkan lebih sering menginfeksi anak-anak khususnya balita (bawah lima tahun) dan diperkirakan berhubungan erat dengan status imun anak. ${ }^{8}$ Penelitian di Jakarta tahun 2008 terdapat 34,6\% kasus kriptosporidiosis pada anak dengan atau tanpa diare. ${ }^{9}$

Gejala klinis infeksi protozoa usus oportunistik sangat luas mulai dari asimptomatik sampai diare persisten. Diare akut yang sembuh sendiri pada individu imunokompeten sampai diare kronis yang fatal pada penderita imunokompromais. ${ }^{3,4}$ Diare yang timbul dapat menyerupai kolera dan menyebabkan kehilangan cairan 3-20 liter per hari sehingga dapat terjadi dehidrasi berat. Walaupun penyakit tersebut dapat sembuh sendiri, tetapi sebanyak $13 \%$ anak yang terinfeksi protozoa usus oportunistik, khususnya Cryptosporidium sp. akan mengalami gejala yang berulang dalam 6 hari sampai 2,5 bulan setelah infeksi yang pertama. ${ }^{4}$

Penularan penyakit infeksi oportunistik ini sangat mudah terutama pada daerah-daerah dengan sanitasi dan higiene yang masih buruk. Gejala yang berulang dan mudahnya penularan infeksi parasit ini akan menyebabkan angka kesakitan yang tinggi yang sangat berpengaruh kepada kualitas hidup pasien. Pada anak - anak khususnya balita, infeksi protozoa usus oportunistik ini secara tidak langsung akan mempengaruhi pertumbuhan dan perkembangannya. ${ }^{4}$

Berdasarkan data yang diperoleh dari Dinas Kesehatan Kota Pekanbaru angka kejadian diare pada bulan Januari sampai bulan November tahun 2010 di Puskesmas Rawat Inap (RI) Kota Pekanbaru cukup tinggi yaitu sebanyak 1.073 kasus. Kejadian terbanyak terdapat di Puskesmas RI Tenayan Raya yaitu sebanyak 258 (24,04 \%) kasus. ${ }^{10}$

Berdasarkan hal di atas yaitu masih tingginya angka kejadian diare pada anak, dan protozoa usus oportunistik dapat merupakan salah satu penyebabnya yang bila tidak diobati akan menyebabkan angka kesakitan yang tinggi. Parasit ini juga masih jarang diteliti dan belum menjadi perbincangan publik di Indonesia, khususnya Pekanbaru. Oleh karena itu peneliti tertarik untuk melakukan penelitian apakah terdeteksi protozoa usus oportunistik pada tinja pasien anak dengan diare di Puskesmas Rawat Inap Kota Pekanbaru.

\section{METODE}

Jenis penelitian ini adalah deskriptif yang menggambarkan protozoa usus oportunistik pada tinja anak diare di Puskesmas Rawat Inap Kota Pekanbaru. Penelitian dilakukan pada bulan April sampai Desember 2012 dan pengambilan sampel dilakukan dari 4 Puskesmas Rawat Inap Pekanbaru yaitu Puskesmas Tenayan Raya, Puskesmas Karya Wanita, Puskesmas Simpang Tiga dan Puskesmas Sidomulyo. Jumlah sampel yang termasuk kriteria inklusi dan eksklusi adalah 76 sampel. Sampel tinja yang diambil adalah tinja segar yang ditampung secara langsung, bukan tinja yang terdapat di popok. Tinja sampel yang sudah dimasukkan kedalam pot tinja besar, sebagian langsung dilakukan pemeriksaan langsung menggunakan lugol, ini dilakukan dalam waktu kurang dari 24 jam, sebagian lagi dipindahkan kedalam pot tinja kecil dan diberi formalin dengan perbandingan $1: 3$. Tinja yang diberi formalin ini yang dilakukan pewarnaan. Pewarnaan yang dilakukan adalah pewarnaan MTA (Modifikasi Tahan Asam) ${ }^{10}$. Setelah dilakukan pewaranan, sampel tinja diperiksa dibawah mikroskop untuk mendeteksi protozoa usus oportunistik. Positif bila ditemukan salah satu protozoa usus oportunistik. Protozoa usus oportunistik yang diperiksa adalah Cryptosporidium sp. Cyclospora sp, Isospora belii dan Blastocystis hominis. Pemeriksaan dilakukan dengan perbesaran 40x dan 100x menggunakan minyak imersi.

\section{HASIL}

Sampel tinja diare anak yang berasal dari 4 Puskesmas Rawat Inap Pekanbaru diperoleh sebanyak 76 sampel. Distribusi responden berdasarkan jenis kelamin dan umur dapat dilihat pada tabel 1. 
Tabel 1. Karakteristik responden berdasarkan jenis kelamin dan umur

\begin{tabular}{ccc}
\hline Karakteristik & $\mathrm{N}$ & $\%$ \\
\hline Jenis Kelamin & & \\
$\bullet \quad$ Laki-laki & 41 & $53,9 \%$ \\
$\bullet \quad$ Perempuan & 35 & $46,1 \%$ \\
\hline Umur & 32 & $42,1 \%$ \\
$\bullet \quad 1-3$ tahun & 30 & $39,5 \%$ \\
$\bullet \quad>3$ - 5 tahun & 14 & 18,4 \\
\hline$>5-10$ tahun & &
\end{tabular}

Tabel 1. Memperlihatkan bahwa penderita diare anak yang terbanyak adalah jenis kelamin lakilaki dengan usia 1-3 tahun.
Berdasarkan penelitian yang telah dilakukan pada penderita diare anak didapatkan infeksi protozoa usus oportunistik sebanyak 22,3\% seperti terlihat pada tabel 2. Infeksi oleh B.hominis lebih banyak ditemukan, seperti yang terlihat pada tabel 3 .

Tabel 2. Sebaran infeksi protozoa usus oportunistik berdasarkan hasil pemeriksaan

\begin{tabular}{ccc}
\hline $\begin{array}{c}\text { Infeksi protozoa usus } \\
\text { oportunistik }\end{array}$ & $\mathrm{N}$ & Persentase (\%) \\
\hline Positif & 17 & 22,3 \\
Negatif & 59 & 77,7 \\
\hline Total & 76 & 100,0 \\
\hline
\end{tabular}

Tabel 3. Sebaran infeksi protozoa usus oportunistik yang positif berdasarkan jenis protozoa usus oportunistik

\begin{tabular}{lc}
\hline \multicolumn{1}{c}{ Hasil Pemeriksaan } & Jumlah $(\mathrm{N}=76)$ \\
\hline Cryptosporidium sp. & $7(9,2 \%)$ \\
Cyclospora cayetanensis & $2(2,6 \%)$ \\
Blastocystis hominis & $8(10,5 \%)$ \\
Isospora belii & - \\
\hline \multicolumn{1}{c}{ Jumlah } & $17(22,3 \%)$ \\
\hline
\end{tabular}

Pada hasil pemeriksaan seperti yang terlihat pada tabel 3 didapatkan 9,2\% tinja penderita diare anak ditemukan Cryptosporidium sp, sedangkan Isospora tidak ditemukan.

Tabel 4. Sebaran hasil pemeriksaan protozoa usus oportunistik berdasarkan umur dan jenis kelamin

\begin{tabular}{|c|c|c|c|c|c|c|}
\hline \multirow{2}{*}{$\begin{array}{l}\text { Karakteristik } \\
\text { berdasarkan }\end{array}$} & \multicolumn{4}{|c|}{ Positif } & \multirow[t]{2}{*}{ Negatif } & \multirow{2}{*}{ Jumlah } \\
\hline & Cryptosporidium & Cyclospora & $\begin{array}{c}\text { Blastocystis } \\
\text { hominis }\end{array}$ & Isospora & & \\
\hline \multicolumn{7}{|l|}{ Jenis kelamin } \\
\hline \multicolumn{7}{|l|}{ Laki-laki } \\
\hline Perempuan & 4 & 0 & 5 & 0 & 32 & 41 \\
\hline & 3 & 2 & 3 & 0 & 27 & 35 \\
\hline \multicolumn{7}{|l|}{ Umur } \\
\hline 1 - 3 tahun & 5 & 1 & 3 & 0 & 23 & 32 \\
\hline$>3-5$ tahun & 2 & 1 & 5 & 0 & 22 & 30 \\
\hline$>5-10$ tahun & 0 & 0 & 0 & 0 & 0 & 14 \\
\hline
\end{tabular}


Pada tabel 4 terlihat bahwa infeksi protozoa usus oportunistik oleh Cryptosporidium sp ditemukan lebih banyak pada anak usia $1-3$ tahun.

\section{PEMBAHASAN}

Sebanyak 76 sampel tinja diare anak yang berasal dari 4 Puskesmas Rawat Inap Pekanbaru, didapatkan penderita diare anak yang terbanyak adalah jenis kelamin laki-laki dengan usia 1-3 tahun. Hal ini sesuai dengan data dari WHO yang menyatakan $80 \%$ penderita diare adalah anak balita terutama di bawah 2 tahun. ${ }^{12}$ Anak-anak yang berusia dibawah tiga tahun (batita) sangat rentan untuk terkena diare, ini disebabkan karena faktor imunitas, higienitas dan karena anak pada usia ini mempunyai kebiasaan suka memasukkan sesuatu ke dalam mulut. Benda-benda yang dimasukkan ke dalam mulut dapat menjadi media infeksi mikroorganisme yang dapat menyebabkan diare. ${ }^{13,14}$

Berdasarkan penelitian yang telah dilakukan pada penderita diare anak didapatkan infeksi protozoa usus oportunistik sebanyak 22,3\%. Infeksi oleh B.hominis lebih banyak ditemukan. Hal ini sesuai dengan penelitian Kurniawan et al $2007^{7}$ di Jakarta pada pasien HIV positif didapatkan sebagian besar 74\% ditemukan B.hominis. B.hominis ini merupakan protozoa usus yang sering ditemukan pada tinja. Sebagian besar ahli berpendapat bahwa B.hominis merupakan protozoa usus komensal di dalam tinja tetapi sebagian lagi pendapat menyatakan bahwa spesies ini merupakan parasit oportunistik yang akan menimbulkan gejala klinis bila status imun penderita menurun.

Pada penelitian ini didapatkan 9,2\% tinja penderita diare anak ditemukan Cryptosporidium $s p$. Hal ini sesuai dengan penelitian yang dilakukan oleh Kassasi R et al. di Abidjan pada tahun 2004 dari 130 anak diare dibawah 5 tahun (balita) yang diperiksa dengan pewarnaan MTA didapatkan infeksi Cryptosporidium sp sebanyak 7,7\%. ${ }^{15} \mathrm{Hal}$ ini sedikit berbeda dengan penelitian Kurniawan A et al 2008 di Jakarta pada sampel anak yang tinggal di pinggiran sungai Ciliwung, didapatkan 4,68\% positif Cryptosporidium sp. menggunakan teknik pewarnaan MTA. Ini mungkin disebabkan karena pada sampel penelitian tersebut menggunakan anak yang diare dan tidak diare, tetapi pada penelitian
Kurniawan A et al tersebut setelah dilakukan pemeriksaan dengan teknik PCR pada sampel yang sama didapatkan hasilnya $34,6 \%{ }^{9}$ yang positif dengan Cryptosporidium. Perbedaan ini disebabkan teknik pemeriksaan yang berbeda karena PCR merupakan teknik pemeriksaan yang mempunyai sensitifitas tinggi.

Pada penelitian ini didapatkan 2 sampel yang positif dengan Cyclospora sedangkan Isospora tidak ditemukan, hal ini mungkin dikarenakan pemeriksaan mikroskopis dengan MTA kurang sensitif dan tinja yang diperiksa tidak dikonsentrasi atau kemungkinan memang tidak ada infeksi Isospora pada semua subjek yang diperiksa.

Infeksi protozoa usus oportunistik oleh Cryptosporidium sp ditemukan lebih banyak pada anak usia $1-3$ tahun. Hal ini sesuai dengan beberapa penelitian bahwa infeksi oleh Cryptosporidium sp lebih banyak ditemukan pada anak batita. Hal ini juga sesuai dengan penelitian oleh Mirzaei M di Korea bahwa infeksi oleh ookista Cryptosporidium sp banyak ditemukan pada anak 1-5 tahun. ${ }^{16}$ Anak pada rentang umur tersebut lebih mudah terpapar dengan ookista Cryptosporidium sp dan pada umur tersebut sisitem imun tubuhnya masih rendah. Hal tersebut dikarenakan kurangnya pengetahuan anak tentang kebersihan makanan dan minuman yang baik. Tidak mencuci tangan sebelum makan, bermain di tanah dan air limbah. Infeksi Cryptosporidium ditularkan melalui fecal-oral. Pada anak-anak yang tidak menjaga kebersihan maka akan sangat rentan terhadap infeksi oleh protozoa usus oportunistik tersebut. ${ }^{17}$

Protozoa usus oportunistik yang ditemukan pada sampel anak dengan diare tersebut belum tentu menimbulkan gejala klinis karena protozoa usus oportunistik ini akan menimbulkan gejala bila status imun penderita menurun dan dikatakan sebagai penyebab penyakit apabila penyebab oleh mikroorganisme lain telah disingkirkan.

\section{SIMPULAN}

Angka kejadian infeksi protozoa usus oportunistik pada tinja anak dengan diare di Puskesmas Rawat Inap Pekanbaru sebanyak 22,3\% dengan infeksi Blastocystis hominis sebesar 10,5\%, infeksi Cryptosporidium sp sebesar 9,2\%,dan 
Cyclospora sebesar 2,6\%. Infeksi oleh Isospora tidak ditemukan.

\section{SARAN}

Perlu dilakukan penelitian lebih lanjut tentang infeksi protozoa usus oportunistik dengan metode tinja konsentrasi supaya pemeriksaan tinja lebih cepat dan mudah dideteksi.

\section{UCAPAN TERIMAKASIH}

Ucapan terimakasih kepada Lembaga Penelitian Universitas Riau dan Dekan Fakultas Kedokteran Universitas Riau serta Kepala Puskesmas Rawat Inap Pekanbaru. Ucapkan terimakasih juga disampaikan kepada Prof. dr. Agnes Kurniawan, Sp.ParK. PhD. dari Departemen Parasitologi FKUI yang telah menyediakan kontrol positif untuk pemeriksaan hasil penelitian ini serta seluruh pihak yang telah membantu penelitian ini.

\section{DAFTAR PUSTAKA}

1. Kusbaryanto, Hidayati T. Gambaran kejadian wabah diare dan faktor-faktor terkait di Senden, kulon, Progo. Jurnal Kedokteran dan Kesehatan Mutiara Medika. Januari 2008;8(1).

2. Dinas Kesehatan Provinsi Riau. Profil Kesehatan Provinsi Riau.2009.

3. Susanto L, Gandahusada S, Coccidia. Dalam Parasitologi Kedokteran. Ed:4. Jakarta: Balai Penerbit FKUI; 2008: 158-79.

4. Sears CL, Kirkpatrick BD. Cryptosporidiosis and isosporiasis. In: Gillespie SH, Pearson RD, editors. Principles and practice of clinical parasitology. New York: John Wiley \& Sons, Inc., 2001; p.139-59.

5. Prasetyo RH. Intestinal Parasites Infection in AIDS patient with chronic diarrhea at Dr.Soetomo General Hospital Surabaya. Indonesia J Trop Infect Dis.2010: 1 (1).36-7.
6. Kulkarni SV, Kairon R, Sane SS, Padmawar PS, Kale VA, Thakar MR, et al. Opportunistic parasitic infections in HIV/AIDS patients presenting with diarrhea by the level immunosupression. J Med Res India. Juli 2009;130: 63-6.

7. Kurniawan A, Smith H. Intestinal protozoa infection in HIV/AIDS patients. 2007.

8. Hunter PR, Nichols G. Epidemiology and clinical features of Cryptosporidium infection in immunocompromised patients. Clin Microbiol Rev. 2002;15(1):145-54.

9. Kurniawan A, Dwintasari SW, Soetomenggola HA, Wanandi SI. Detection of Cryptosporidium sp infections by PCR and modified acid fast staining fron pottasium dichromate preserved stool. Medical Journal of Indonesia. 2009;18(3).

10.Dinas Kesehatan Kota Pekanbaru. Rekap penderita diare bulan Januari s/d November. 2010.

11. Gracia LS, bruckner DA.Diagnostik Parasitologi Kedokteran. Jakarta: EGC: 2002;41-6.

12.WHO. Diarrhoeal Disease; 2009 [di akses 22 Oktober 2012]. Available from: http: // www.who.int/mediacenter/factsheets.

13.Mansjoer et al. Ilmu Kesehatan Anak, Jilid I. Jakarta: Infomedika Jakarta, 1998

14.Putra DS. diare akut pada anak [diakses tanggal 17 april 201]). http://www.dr-rocky.com/layoutartikel.../42-diare-akut-pada-anak

15.Kassi RR. Kouassi RA, Yavo W, Barro-Kiki CP, Bamba A, Menan HI.dkk. Crptosporidiosis and Isosporiasis in children suffering from diarrhoea in Abidjan. Nov 2004;97(4):280-2.

16.Mirzaei M. Prevalence of Cryptosporidium sp infection in diarrhea and non-diarrheic humans in Iran. Korean J Parasitol.2007;45 (2):133-7.

17.Maryanti E. Epidemiologi kriptosporidiosis. Jurnal Ilmu Kedokteran. 2011: 5(1):1-6. 